\title{
ACID-BASE DISARRANGEMENT AND GASTRIC INTRAMUCOSAL ACIDOSIS PREDICT OUTCOME FROM MAJOR TRAUMA
}

José O. Calvete, Leonardo Schonhorst, Diego M. Moura, Gilberto Friedman*

Trabalho realizado na Universidade de Passo Fundo - Hospital Universitário São Vicente de Paulo, Passo Fundo, RS

\author{
*Correspondência: \\ Departamento de Medicina \\ Interna-FAMED-UFRGS \\ Rua Fernandes Vieira 181/ \\ 601 - Porto Alegre - RS \\ Cep 90035-091 \\ Tel: (51)3311-6649 \\ FAX: (51)3330-7807 \\ gfriedman@ hcpa.ufrgs.br
}

\begin{abstract}
SUMMARY
INTRODUCTION. This prospective non-interventional study intended to assess the prognostic value of gastric intramucosal acidosis in patients with severe trauma admitted to a medical/surgical ICU.

Metrods. Gastric tonometer catheters were introduced to measure air $\mathrm{PCO}_{2}$ level (Tonocap device) in forty consecutive critically ill trauma patients. Gastric intramucosal pH, air $\mathrm{PCO}_{2}$ gradient, lactate and acid-base parameters were measured at admission and at 6, 12 and $24 \mathrm{~h}$ thereafter.

REsuLTs. The median age, mean APACHE $I I$ and SOFA scores were higher in nonsurvivors than in survivors $(p<0.05)$. There were significant differences in the $\mathrm{PCO}_{2}$ gradient between survivors and nonsurvivors at 12 and 24 hours ( $10 \pm 7$ vs. $24 \pm 19$ $\mathrm{mmHg}, 13 \pm 16$ vs. $29 \pm 25 \mathrm{mmHg} ; \mathrm{p}<0.05)$. Gastric intramucosal $\mathrm{pH}$ values were lower in nonsurvivors than in survivors, on admission and after 12 or 24 hours $(\mathrm{p}<0.05)$. Arterial pH and bicarbonate were lower, lactate concentration higher, and base excess more negative in nonsurvivors. Prediction of outcome (mortality and MODS) at 24 hours of ICU assessed by their ROC curves was similar ( $\mathrm{p}=\mathrm{NS}$ ). At 24 hours, air $\mathrm{PCO}_{2}$ gradient $>18 \mathrm{mmHg}$ carried a relative risk of 4.6 for death, slightly higher than a $\mathrm{HCO}_{3}<20 \mathrm{mEq} / \mathrm{L}(\mathrm{RR}=4.29)$ or base excess of $<-2 \mathrm{mmol} / \mathrm{L}(\mathrm{RR}=3.65)$.

Conclusion. Bicarbonate, base deficit, lactate, gastric intramucosal pH and $\mathrm{PCO}_{2}$ gradient discriminate sunvivors from nonsurvivors of major trauma. A critical air $\mathrm{PCO}_{2}$ gradient carried the greatest relative risk for death at 24 hours of ICU. Inadequate regional blood flow as detected by a critical $\mathrm{PCO}_{2}$ gradient seems to contribute to morbidity and mortality of severe trauma patients.
\end{abstract}

KEY WORDS: Trauma. Mortality. Splanchnic perfusion. Gastric tonometry. Outcome prediction.

\section{INTRODUCTION}

In Brazil, traumatic injury is the leading cause of loss of life before 50 years of age'. As in other critically ill patients admitted to an intensive care unit (ICU), multiple organ dysfunction syndrome (MODS) is the most common cause of death 2:3. Incomplete resuscitation has been associated to development of MODS and death ${ }^{4-8}$. There is conclusive evidence that global parameters fail to accurately address the adequacy of resuscitation in a number of clinical conditions ${ }^{4,6-9}$, including trauma patients ${ }^{10-13}$. Significant splanchnic ischemia can be present despite apparently complete global resuscitation and may ultimately result in the development of MODS ${ }^{14}$.

Previous studies have shown that blood lactate and base deficit are good predictors of mortality even in a context of normalized vital signs, such as blood pressure, urine output, and heart rate ${ }^{9,15}$. Both indices of resuscitation are however representative of an overall condition, some degree of regional inadequate perfusion or oxygenation that may persist in the splanchnic bed. Gastric intramucosal $\mathrm{pH}(\mathrm{pHi})$, calculated from the gastric tonometer was developed to assess the degree of perfusion of the gut mucosa, which is particularly sensitive to a blood flow reduction. Several clinical studies have associated intramucosal pH values with morbidity and mortality rates of critically ill and trauma patients ${ }^{45 ; 5-5 ; ; 11 ; 12 ; 16 ; 17}\left({ }^{10 ; 16 ; 18}\right)$.
Although pHi is a good prognostic marker, apparently it is not a useful monitoring variable to follow the effect of treatment on gastric perfusion because it is encumbered by technical problems and influenced by the systemic acid-base status ${ }^{19-21}$.

$\mathrm{PCO}_{2}$ gradient (the difference between gastric mucosal $\mathrm{PCO}_{2}$ and arterial $\mathrm{PCO}_{2}$ ) is the chosen monitoring variable ${ }^{21: 22}$. Nevertheless, few studies have evaluated if a critical $\mathrm{PCO}_{2}$ gradient is associated with a worse outcome, particularly in trauma patients, however, most were using saline

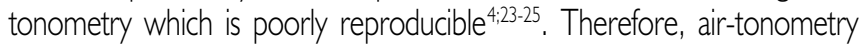
is a more precise technique, furthermore there are no records of a study that evaluated $\mathrm{PCO}_{2}$ gradient using this technology in trauma patients.

The primary purpose of this study was to evaluate the relationship between the state of splanchnic perfusion and mortality and morbidity in critically ill trauma patients. Thus, this study prospectively investigated the prognostic value of $\mathrm{PCO}_{2}$ gradient in a group of severely traumatized patients and compared it with metabolic markers of tissue hypoperfusion.

\section{Methods}

\section{Study design}

Prospective, descriptive study in the interdisciplinary ICU of a university hospital 


\section{Patient population}

Inclusion Criteria

Forty consecutive traumatized patients with hemodynamic instability, admitted at a medical/surgical intensive care unit, in whom central venous catheters had been inserted to guide resuscitation, were evaluated over a period of one year. The Ethics Committee of Hospital São Vicente de Paulo approved the study.

\section{Exclusion criteria}

Patients were excluded if placement or manipulation of a nasogastric tube was contraindicated (e.g. Major stomach reconstruction or nasopharyngeal or esophageal obstruction and active upper gastrointestinal tract bleeding).

\section{Measurements}

Central venous catheters and tonometric nasogastric tubes were placed on patients' arrival at the ICU. Arterial blood gases, arterial blood lactate and intramucosal $\mathrm{PCO}_{2}$ were simultaneously obtained upon study admission, and 6, 12 and 24 h later. A gastric tonometer (Tonometrics, Hopkinton, MA, USA) was introduced and the correct position confirmed by injecting air through the tube and auscultating a gurgling sound in the stomach and aspirating a small amount of gastric fluid. Subsequently, the gastric tonometer was connected to an automated gas analyzer (Tonocap TC-200; Datex, Helsinki, Finland). Before use, the Tonocap monitor was calibrated (Quick Cal Calibration Gas). Prior to air sampling from the balloon catheter, enteral feeding was discontinued for I h and nasogastric suction was discontinued for $30 \mathrm{~min}$. All patients received ranitidine (I 50 $\mathrm{mg} /$ day) intravenously. The gastric $\mathrm{PCO}_{2}$ gap was calculated by subtracting the temperature-corrected arterial $\mathrm{PCO}_{2}$ from gastric $\mathrm{CO}_{2}$. Blood-gas values were entered via the Tonocap keyboard for calculation of gastric $\mathrm{pHi}$, with $\mathrm{pHi}=\mathrm{pHa}-\log$ (gastric tonometered $\mathrm{PCO}_{2} / \mathrm{PaCO}_{2}$ ). Concentration of arterial blood lactate was measured enzymatically (Cobas Mira Plus, Roche). Development of organ dysfunction was evaluated using the Sequential Organ Failure Assessment score (SOFA) at admission and 3, 7,10,14,21 and 28 days thereafter ${ }^{26}$. Patients were followed up until death or discharge from the hospital. The clinical diagnosis of MODS was established on the basis of the SOFA score, with a minimum score of 3 and more than two organs affected.

\section{Statistical analysis}

An unpaired Student's t-test for normally distributed variables or a Mann-Whitney test for non-normally distributed variables were used to compare differences within groups at study admission. Changes over time were analyzed using a two-way analysis of variance for repeated measurements. A Newman-Keuls test was used for post-hoc comparisons.

Receiving operating characteristics (ROC) curves were constructed to analyze the discriminating power of each variable to predict mortality and development of MODS at 24 hours of ICU. Based on previous studies, a $\mathrm{pHi}<7.32, \mathrm{PCO}_{2}$ gradient $>18 \mathrm{mmHg}$, arterial Base Deficit $>2 \mathrm{mmol} / \mathrm{L}$, arterial $\mathrm{HCO}_{3}<20 \mathrm{mEq} / \mathrm{L}$ and an arterial lactate $>2.2$ $\mathrm{mmol} / \mathrm{L}$ were considered critical for the purpose of this study $(1 ; 25)$. The one-tailed Fisher exact test was used to determine significant differences in the proportions for survival in each variable. Sensitivity, specificity, positive predictive value (PPV), negative predictive value (NPV), and the relative risk of death (RR=PPV/I-NPV) were calculated for each variable. The RR ratio implies the likelihood of nonsurvival among patients with critical values as compared with the likelihood of death among patients with normal values. A $p<0.05$ was considered significant. Data are reported as mean \pm SD for normally distributed variables and median (25-75th percentiles) for non-normally distributed variables.

Based on previous studies about the prognostic value of gastric tonometry, we expected to recruit 43 patients (significance level 0.05 , power $80 \%$ ).

\section{Results}

The clinical characteristics of survivors and nonsurvivors are listed in Table I. Forty patients were enrolled in the study. Patients had a median age of 35 (14-79) years and a mean Acute Physiology and Chronic Health Evaluation II (APACHE II) score of $16 \pm 7^{27}$. Thirty-six were male (90\%). Hospital mortality rate was 38\% (15/40) and 22 patients developed multiple organ dysfunction syndrome (MODS). Median ICU stay was of 5 [2-12) days. Fourteen patients died in the intensive care unit (five in less than 24 hours) and 25 were discharged alive from the hospital. Nonsurvivors APACHE II and SOFA scores substantially exceeded those of survivors indicating a more significantly injured population.

Time courses of the analyzed variables are shown in Table 2 and Figures I and 2. Nonsurvivors were more tachycardic and had a lower mean arterial pressure than survivors but differences were only significant after 24 hours. Urine output was the same for survivors and nonsurvivors during the 24 hours period $(2910 \pm 1419$ vs. $217 \mid \pm 1546, p=205)$. Upon study admission, 29 (73\%) patients had an increased blood lactate concentration. However, blood lactate levels remained high in nonsurvivors and progressively decreased in survivors, so that differences became significant at 6, 12 and $24 \mathrm{~h}$ after (Figure I). Blood lactate levels were not measured in 10 patients at $24 \mathrm{~h}$ ( 3 survivors and 7 nonsurvivors). Arterial bicarbonate and base excess had a course similar to blood lactate and differences became significant at 6, 12 and $24 \mathrm{~h}$ (Figure I). Nonsurvivors were more acidemic and arterial pH did not show any improvement after $24 \mathrm{~h}$. During the first $24 \mathrm{~h} \mathrm{pHi} \mathrm{values} \mathrm{were} \mathrm{significantly}$ higher in survivors than in nonsurvivors. In addition, $\mathrm{PCO}_{2}$ gradient values were lower in survivors than in nonsurvivors and the differences became significant at $\mathrm{I} 2$ and $24 \mathrm{~h}$ (Figure 2).

The ability of each metabolic variable to predict mortality and MODS at 24 hours was tested. Accuracy (area under the curve) of the receiver operating curves for mortality and MODS was similar $(p=N S)$ for all studied variables Sensitivity, specificity and best cutoff point for mortality are shown in Table 3. A critical $\mathrm{PCO}_{2}$ of $18 \mathrm{mmHg}$ gradient had a $67 \%$ sensitivity and an $83 \%$ specificity to predict nonsurvival with a 4.6 RR for death, greater than any other variable evaluated, but similar to arterial bicarbonate (Table 4).

\section{Discussion}

The Hospital São Vicente de Paulo at the University of Passo Fundo evaluates approximately 1000 trauma cases per year of which 90 are admitted to the ICU. The aim of this study was to determine if gastric intramucosal acidosis measured by gastric tonometry, as a reflection of regional hypoperfusion, provided a better predictor of mortality in a subset of 40 very ill traumatized patients. In this study, gastric intramucosal acidosis appeared as a good predictor of mortality or MODS, together 


\begin{tabular}{lccc}
\hline \multicolumn{3}{c}{ Table 1 - Descriptive characteristics of survivors and nonsurvivors } \\
\hline Variable & Survivors & Nonsurvivors & $\begin{array}{c}\text { P value (Fischer's } \\
\text { test or } \\
\text { Student'st-test) }\end{array}$ \\
\hline No. Patients & 25 & 15 & \\
Age, years & $27[19-36]$ & $45[28-64]$ & 0.002 \\
APACHE II & $13 \pm 5$ & $21 \pm 7$ & 0.001 \\
RTS & $5.7 \pm 1.6$ & $4.7 \pm 1.7$ & 0.058 \\
Duration of ICU stay, days & $7[3-15]$ & $4[1-7]$ & 0.001 \\
Duration of Hospital stay, days & $24[1|-| 1]$ & $4[2-8])$ & 0.002 \\
SOFA & $5.5 \pm 4$ & $12 \pm 6$ & 0.002 \\
Creatinine & $0.8[0.7-1.0]$ & $1.3[1.1-1.9]$ & 0.001 \\
Automobile vs. pedestrian, No & 3 & 3 & 0.666 \\
Automobile vs. automobile & 12 & 6 & 1.000 \\
Motorcycle accident & 3 & 4 & 0.417 \\
Others & 7 & 2 & 0.467 \\
\hline Data & & &
\end{tabular}

Data are expressed as mean \pm SD or median (percentiles $25 \%-75 \%$ )

Acute physiology and chronic health evaluation II - APACHE II, Revised trauma score - RTS Sequential organ failure assessment score - SOFA.

\begin{tabular}{|c|c|c|c|c|}
\hline & Admission & 6 hours & 12 hours & 24 hours \\
\hline \multicolumn{5}{|l|}{$\overline{\mathrm{HR}}$} \\
\hline$S$ & $102 \pm 28$ & $104 \pm 24 *$ & $102 \pm 27$ & $97 \pm 20 *$ \\
\hline NS & $112 \pm 27$ & $123 \pm 21$ & $117 \pm 22$ & $116 \pm 24$ \\
\hline \multicolumn{5}{|c|}{ MAP } \\
\hline$S$ & $92 \pm 16$ & $87 \pm 12$ & $93 \pm 23$ & $92 \pm 13^{*}$ \\
\hline NS & $92 \pm 21$ & $86 \pm 23$ & $81 \pm 20$ & $76 \pm 20$ \\
\hline \multicolumn{5}{|l|}{ pH } \\
\hline $\begin{array}{l}\mathrm{S} \\
\text { NS }\end{array}$ & $\begin{array}{l}7.36 \pm 0.07 * \\
7.31 \pm 0.10\end{array}$ & $\begin{array}{l}7.40 \pm 0.08 * \\
7.31 \pm 0.12\end{array}$ & $\begin{array}{l}7.40 \pm 0.05 \\
7.35 \pm 0.13\end{array}$ & $\begin{array}{c}7.41 \pm 0.07 *, \# \\
7.34 \pm 0.12\end{array}$ \\
\hline \multicolumn{5}{|c|}{$\mathrm{PCO}_{2}(\mathrm{mmHg})$} \\
\hline$S$ & $38.4 \pm 5.2$ & $37.0 \pm 5.7$ & $38.8 \pm 4.8$ & $38.7 \pm 5.8$ \\
\hline NS & $39.2 \pm 8.2$ & $37.7 \pm 7.9$ & $33.8 \pm 6.8$ & $35.7 \pm 6.7$ \\
\hline \multicolumn{5}{|c|}{$\mathrm{PO}_{2}(\mathrm{mmHg})$} \\
\hline S & $105[78-178]$ & $99[8|-| 5 \mid]$ & $92[7 \mid-144]$ & $82[67-133]$ \\
\hline NS & $119[78-221]$ & $108[60-179]$ & $94[77-147]$ & $76[65-107]$ \\
\hline
\end{tabular}

S, survivors; NS, nonsurvivors;

Data are expressed as mean \pm SD or median (percentiles $25 \%-75 \%$ )

${ }^{*} p<0.05$ and ${ }^{*} p<0.01$ between groups

$\# p<0.0$ I vs. admission

with other metabolic markers of hypoperfusion. A critical $\mathrm{PCO}_{2}$ gradient atter 24 hours of ICU carried the highest relative risk of death in comparison with other markers of acid-base derangement, and indicates that splanchnic hypoperfusion contributes to excessive death in this particular population of severe trauma patients.

All metabolic markers of acidosis indicating hypoperfusion showed improvement in survivors after $24 \mathrm{~h}$. All outcome parameters were evaluated at 0, 6 I2, and $24 \mathrm{~h}$ after ICU admission. Global parameters of metabolic hypoperfusion showed differences between survivors and nonsurvivors. Although upon admission the mean value of $\mathrm{PCO}_{2}$
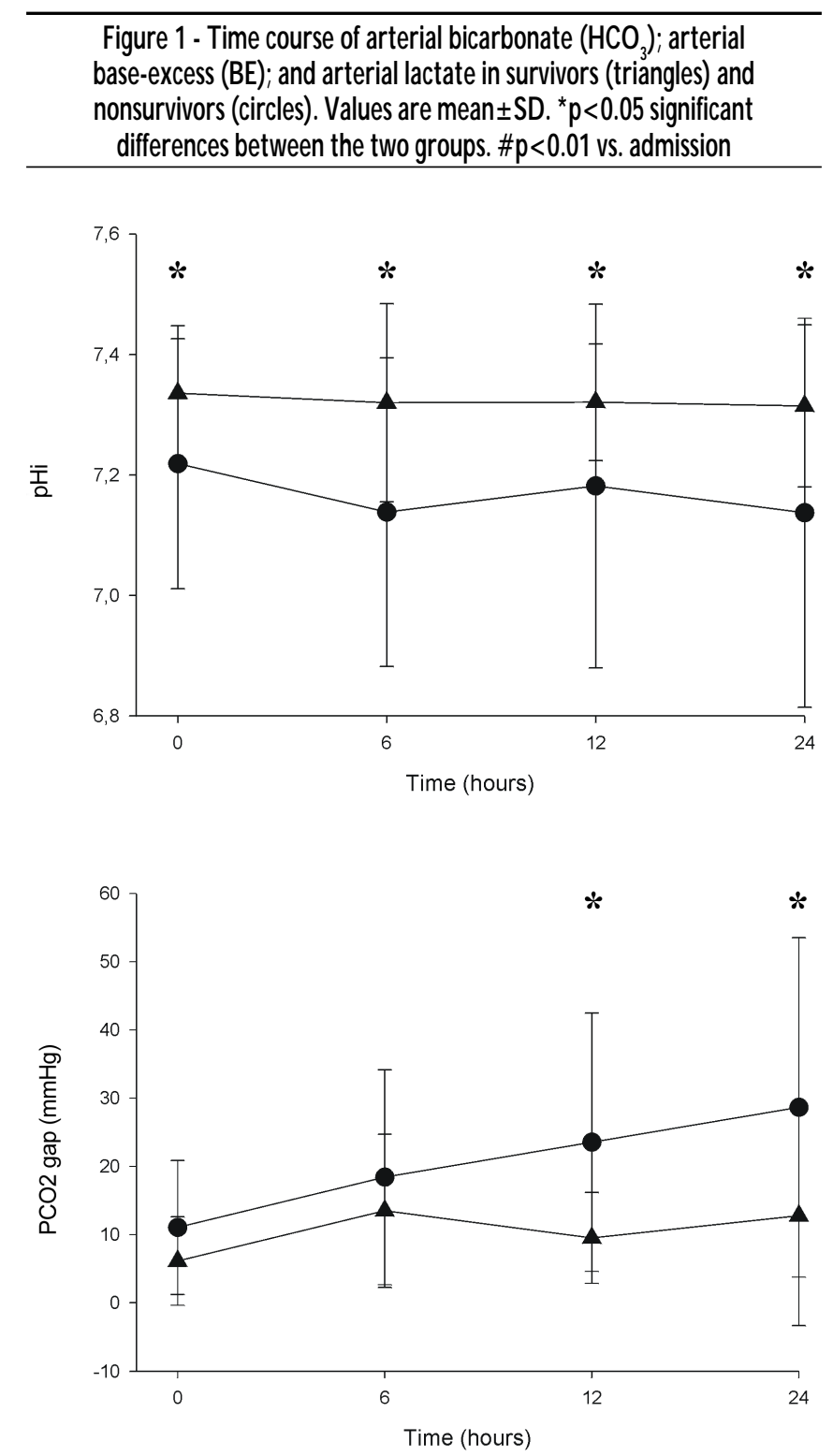

gradient was rather low, both for survivors and nonsurvivors, it became higher than $18 \mathrm{mmHg}$ after 6 hours for $47 \%(7 / 15)$ of nonsurvivors, but for only $28 \%(7 / 25)$ of survivors. While we expected that at ICU admission, a higher degree of gastric hypoperfusion would be present in most nonsurvivors, we speculated that fluid resuscitation was properly performed in the emergency room and transient regional perfusion was adequate but rapidly deteriorated.

Our data support earlier studies that a significantly deranged $\mathrm{pH}, \mathrm{BE}$, bicarbonate, lactate and intramucosal pH or gastric $\mathrm{PCO}_{2}$ gradient correlates with poor outcome(15). Several studies showed that systemic hemodynamic or even metabolic variables were worse predictors of outcome than gastric acidosis(4-6; 10-12). Vital signs such as mean arterial 

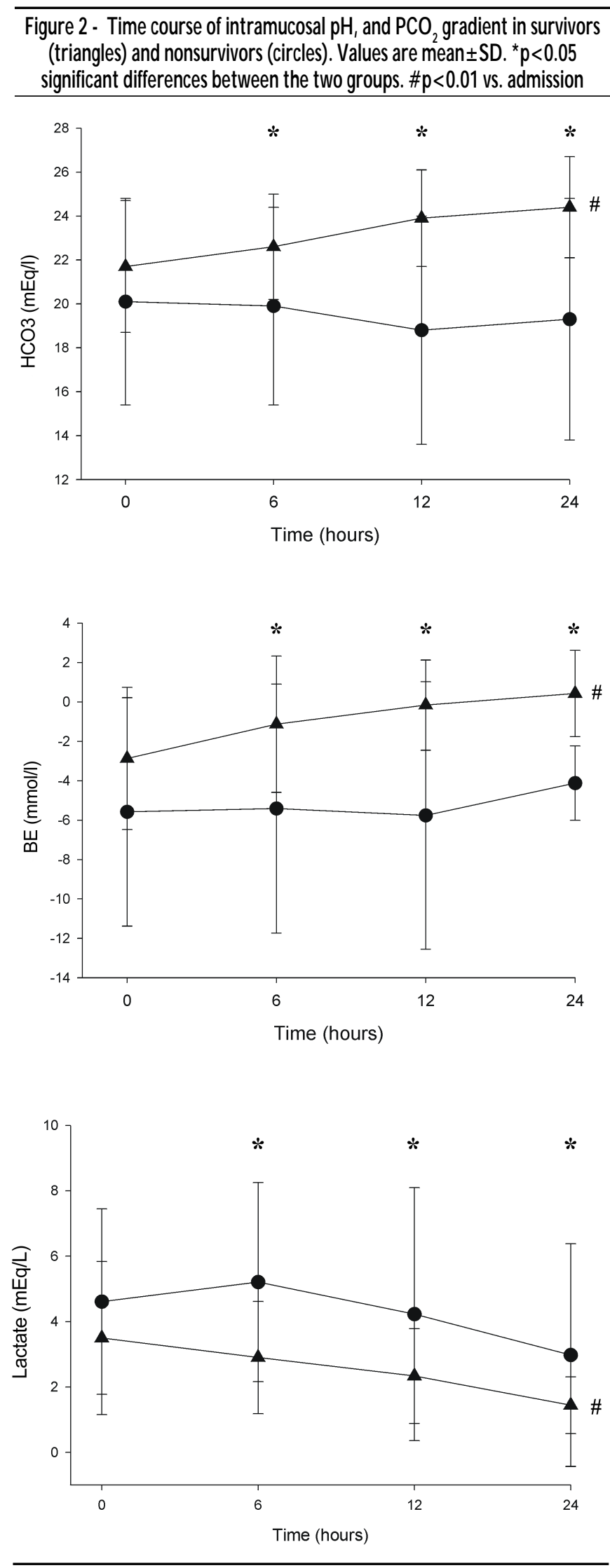

\begin{tabular}{|c|c|c|c|c|c|}
\hline & $\begin{array}{c}\mathrm{pCO}_{2} \text { gradient } \\
(\mathrm{mmHg}) \\
\mathrm{n}=34\end{array}$ & $\begin{array}{c}\mathrm{PHi} \\
\mathrm{n}=34\end{array}$ & $\begin{array}{c}\text { Lactate } \\
\text { (mmol/L) } \\
\mathrm{n}=30\end{array}$ & $\begin{array}{c}\mathrm{BE} \\
(\mathrm{mmol} / \mathrm{L}) \\
\mathrm{n}=35\end{array}$ & $\begin{array}{c}\mathrm{HCO}_{3} \\
(\mathrm{mEq} / \mathrm{l}) \\
\mathrm{n}=35 \\
\end{array}$ \\
\hline Mortality ROC area & 0.693 & 0.602 & 0.582 & 0.723 & 0.780 \\
\hline MODS ROC area & 0.747 & 0.767 & 0.772 & 0.761 & 0.741 \\
\hline Best Cut-off value & $>13.8$ & $<7.15$ & $>2.3$ & $<-1.1$ & $<20$ \\
\hline Sensitivity, \% & 70 & 55 & 38 & 73 & 73 \\
\hline Specificity, \% & 83 & 90 & 91 & 88 & 96 \\
\hline
\end{tabular}

$\mathrm{PHi}$, gastric intramucosal $\mathrm{PH} ; \mathrm{HCO}_{3}$, bicarbonate; $\mathrm{BE}$, base-excess.

\begin{tabular}{|c|c|c|c|c|c|}
\hline & $\begin{array}{c}\mathrm{pCO}_{2} \text { gradient } \\
(\mathrm{mmHg}) \\
\mathrm{n}=34\end{array}$ & $\begin{array}{c}\mathrm{PHi} \\
\mathrm{n}=34\end{array}$ & $\begin{array}{c}\text { Lactate } \\
\text { (mmol/L) } \\
\mathrm{n}=30\end{array}$ & $\begin{array}{c}\mathrm{BE} \\
(\mathrm{mmol} / \mathrm{L}) \\
\mathrm{n}=35\end{array}$ & $\begin{array}{c}\mathrm{HCO}_{3} \\
(\mathrm{mEq} /) \\
\mathrm{n}=35\end{array}$ \\
\hline Critical value & $>18$ & $<7.32$ & $>2.2$ & $<-2$ & $<20$ \\
\hline Fisher's test & $P=0.006$ & $P=0.012$ & $P=0.10$ & $P=0.007$ & $P=0.002$ \\
\hline Sensitivity, \% & 67 & 55 & 38 & 45 & 55 \\
\hline Specificity, \% & 83 & 61 & 84 & 96 & 95 \\
\hline RR & 4.6 & 1.52 & 2 & 3.65 & 4.29 \\
\hline PPV, \% & 60 & 40 & 50 & 83 & 53 \\
\hline NPV, \% & 87 & 74 & 75 & 79 & 74 \\
\hline
\end{tabular}

$\mathrm{PHi}$, gastric intramucosal $\mathrm{PH} ; \mathrm{HCO}_{3}$, bicarbonate; $\mathrm{BE}$, base-excess.

pressure and heart rate became different only after 24 hours, while the other variables identified survival after 12 and even 6 hours. In addition, only $3(8 \%)$ of the patients were hypotensive (PAM>65 mmHg) at 24 hours. In our study, a critical $\mathrm{PCO}$ gradient carried the highest relative risk for mortality at 24 hours, similar to bicarbonate. However, when looking at the ROC curves, systemic metabolic measurements (particularly base excess and bicarbonate) discriminated nonsurvival or development of MODS as well as the $\mathrm{PCO}_{2}$ gradient.

These results display the multifactorial nature of the acid load that occurs with critical illness, even if the initial component is mainly hemorrhagic shock as in trauma patients. These patients were evaluated after significant fluid resuscitation with normal saline solution so that the impact of chloride loading on the outcome cannot be ruled out ${ }^{28}$.

Nevertheless, this study addresses a concern of the importance of hypoperfusion to discriminate survivors and nonsurvivors. Our data confirms that metabolic parameters can identify patients that will die even after global resuscitation is achieved ${ }^{4,9 ; 1 ;: 13,25}$. Our patients were aggressively resuscitated in the emergency room and even at ICU admission and, particularly, after 12-24 hours, however, several patients continued to show evidence of hypoperfusion. Further our data suggested a strong relationship between a higher $\mathrm{PCO}_{2}$ gradient and death or MODS. Several studies in the decade of the 90's addressed the importance of gastric acidosis using saline tonometry in trauma patients ${ }^{10-12: 24}$. Studies that targeted a pHi $<7.32$ as a 
cutoff value showed that patients with $\mathrm{pHi}<7.32$ at admission or whose $\mathrm{pH}$ did not correct within the initial $24 \mathrm{~h}$ had a higher mortality and a higher incidence of MOSF 1:12:29. However, only a few studies on critically ill or trauma patients have investigated the prognostic value of the $\mathrm{PCO}_{2}$ gradient, but most were using saline tonometry. Several studies were negative for $\mathrm{PCO}_{2}$ gradient as a marker of mortality but some showed $\mathrm{pHi}$ as a discriminating factor. On the other hand, other studies like ours have shown that the $\mathrm{PCO}_{2}$ gradient, when measured by regional capnography with air tonometry has good prognostic value. Saline measurements are poorly reproducible and yield a lower gastric $\mathrm{PCO}_{2}$ gradient.

Three studies have evaluated trauma resuscitation guided by a gastric tonometer but all used intramucosal $\mathrm{pH} \mathrm{H}^{0 ; 16 ; 18}$. Two small studies showed positive results ${ }^{10: 16}$ but a third larger study, comparing three resuscitation approaches in two groups of severe traumatized patients with resuscitation guided by gastric tonometry, did not show differences in mortality or morbidity rates ${ }^{18}$. Although pHi is a good prognostic marker, it does not appear to be a useful monitoring variable if the effect of treatment on gastric perfusion is to be followed. Previous studies showed a threshold value of the $\mathrm{PCO}_{2}$ gradient of around 18 $\mathrm{mmHg}$ in unstable, critically ill and trauma patient ${ }^{24,25}$. Our patient population was rather small and we did not intend to propose a new critical value for any variable studied. Interestingly, all identified cutoff points were close to those found in previous studies. We found a cutoff point of $13.8 \mathrm{mmHg}$ for a $\mathrm{PCO}_{2}$ gradient (sensitivity $70 \%$, specificity $83 \%$ ) with $30 \%$ of included patients above that point after 24 hours, yielding a different mortality (58\% vs. II\%).

High blood lactate in globally resuscitated patients also appears to be a predictor of morbimortality in traumatized and critically ill patients. In trauma patients, persistence of hypoperfusion is associated with increased morbimortality, and early correction seems to improve the outcome ${ }^{13: 30 ; 31}$. In high risk surgical patients, we have shown that occult hypoperfusion was a marker of organ dysfunction and death even after hemodynamically stable trans-operative and early postoperative periods?. This study showed that blood lactate levels were significantly higher for nonsurvivors, already after 6 hours and remained stable until 24 hours, while they decreased in survivors. The area under the curve was fair (0.582) and the RR was 2, both lower in comparison to a $\mathrm{PCO}_{2}$ gradient, bicarbonate or base deficit. Unfortunately, lack of blood lactate levels in 10 patients (7 nonsurvivors) at 24 hours may have biased findings.

The arterial bicarbonate and base deficit remain common markers in the ICU, both to diagnose presence of metabolic acidosis and to guide resuscitation ${ }^{32-34}$. In medical, surgical and trauma patients, several series have demonstrated that admission bicarbonate or base deficit is predictive of hospital mortality and morbidity 15:32-36. Our data confirm that nonsurvivors in a trauma ICU population have significant acid-base derangements and that both, the admission and serially obtained base deficit or bicarbonate, are predictive of ICU mortality. Although these markers have proven to be useful for prognosis and even to guide therapy, there are several drawbacks to their use. Acid-base homeostasis may be influenced by acute alcohol intoxication, significant renal dysfunction, large volume crystalloid resuscitation or presence of hypoalbuminemia.

The interpretation of tonometer parameters is not simple. The intramucosal $\mathrm{pH}$ value may underestimate tissue $\mathrm{pH}$ and in part reflects systemic acid load ${ }^{37}$. In our study, pHi ability to predict outcomes was lower than $B E$ or bicarbonate $(p=N S)$. As in other studies, we found that $\mathrm{PCO}_{2}$ gradient values were not significantly different between survivors and nonsurvivors at admission and 6 hours later while pHi was lower in nonsurvivors since admission. As such, probably pHi values were affected already at admission by inclusion of arterial $\mathrm{pH}$ in the calculation. Furthermore, the exact significance of the $\mathrm{PCO}_{2}$ gradient remains unclear and additional factors other than changes in mucosal blood flow may affect gastric mucosal hypercarbia.

Limitations of our study include a relatively small population with a high severity, lack of data on type of and amount of fluid resuscitation in the emergency room and lack of blood lactate measurement in 10 patients (7 nonsurvivors) at 24 hours.

Effective management of shock depends on titration of therapies against reliable resuscitation end points. Conventional clinical and laboratory indices of shock are often insufficient to identify ongoing circulatory impairment. Hypoperfusion identified by blood lactate, acid-base derangement or gastric intramucosal acidosis may compound the initial and subsequent insult causing organ dysfunction and death(38;39). Trauma patients with evidence of hypoperfusion have had poor outcomes. By detecting the presence of tissue acidosis as a proxy of ongoing hypoperfusion, gastric tonometry may facilitate a more timely and rational shock resuscitation.

In summary, we have demonstrated that gastric acidosis lasting longer than 24 hours is a risk factor for the development of organ dysfunction and death. However, it was not evidently a better predictor of survival than other markers of systemic acidosis. Further studies are still needed to demonstrate whether the identification and correction of gastric acidosis may be important to minimize both organ dysfunction and mortality in severe trauma patients.

\section{Conflict of interest: none}

\section{Resumo}

\section{Desarranjo ácido-base e acidose gástrica intramucosal PREDIZEM DESFECHO DE TRAUMA GRAVE}

INTRODUÇÃO. Oobjetivo deste estudo prospectivo, não-intervencionista, foi avaliar o valor prognóstico da acidose gástrica intramucosal em pacientes com trauma grave admitidos numa UTI.

MÉTOdos. Cateteres tonométricos gástricos foram introduzidos para medir o nivel de $\mathrm{PCO}_{2}$ aéreo em 40 pacientes traumatizados. OpH gástrico intramucosal, o gradiente de $\mathrm{PCO}_{2}$ aéreo, o lactato e os parâmetros ácidobase foram medidos na admissão e 6, 12 e 24 h após a admissão.

RESULTADOS. Aidade mediana, OAPACHE Il e os escores SOFA médios forammaioresnosnão-sobreviventesquenossobreviventes $(p<0.05)$. Não houve diferenças significativas para o gradiente de $P C O$ entre sobreviventes e não-sobreviventes após 12 e 24 horas ( $10 \pm 7 v s$. $24 \pm 19 \mathrm{mmHg}, 13 \pm 16$ vs. $29 \pm 25 \mathrm{mmHg} ; P<0.05)$. Os valores de $\mathrm{pH}$ gástrico intramucosal foram menoresnosnão-sobreviventes quenossobreviventesnaadmissãoeapós 12 ou 24 horas $(P<0.05)$. O pH arterial e o bicarbonato foram menores, a concentração de lactato maior, o excesso de base mais negativo nos nãosobreviventes. Predição do desfecho (mortalidade e FMOS) nas 24 horas de UTI acessada pelas curvas ROC foi similar ( $p=N S)$. Nas 24 horas, um 
gradiente de $\mathrm{PCO}_{2}$ aéreo $>18 \mathrm{mmH}$ gacarretou um risco relativo de 4.6para óbito, umpoucomaiorque um $\mathrm{HCO}_{3}<20 \mathrm{mEq} /(\mathrm{RR}=4.29)$ ouumexcesso de base $<-2 \mathrm{mmo} / \mathrm{L}(R R=3.65)$.

Conclusão. Bicarbonato, déficit de base, lactato, pH gástrico intramucosal e o gradiente de $P \mathrm{PO}_{2}$ discriminaram os sobreviventes dos não-sobreviventes de trauma. Um gradiente crítico de $P C \mathrm{C}_{2}$ aéreo acarretou o maior risco relativo para óbito após 24 horas de UTI. Fluxo sangüineo regional inadequado detectado por um gradiente crítico de $\mathrm{PCO}_{2}$ parece contribuir para a morbidade e mortalidade de pacientes traumatizados graves. [Rev Assoc Med Bras 2008; 54(2): I16-2I]

Unitermos: Trauma. Mortalidade. Perfusão esplâncnica. Tonometria gástrica. Prediçãa de desfecho.

\section{REFERÊNCIAS}

I. Tannebaum RD, Arnold JL, De Negri FA, Spadoni VS. Emergency medicine in Southern Brazil. Ann Emerg Med. 200 I;37(2):223-8.

2. Guidet B, Aegerter P, Gauzit R, Meshaka P, Dreyfuss D. Incidence and impact of organ dysfunctions associated with sepsis. Chest. 2005; I27(3):942-5I.

3. Brealey D, Singer M. Multi-organ dysfunction in the critically ill: epidemiology, pathophysiology and management. J R Coll Physicians Lond. 2000;34(5):424-7.

4. Friedman G, Berlot G, Kahn RJ, Vincent JL. Combined measurements of blood lactate concentrations and gastric intramucosal $\mathrm{pH}$ in patients with severe sepsis. Crit Care Med. 1995;23(7): 1 184-93.

5. Doglio GR, Pusajo JF, Egurrola MA, Bonfigli GC, Parra C, Vetere L, et al. Gastric mucosal pH as a prognostic index of mortality in critically ill patients. Crit Care Med. 1991;19(8): 1037-40.

6. Marik PE. Gastric intramucosal pH. A better predictor of multiorgan dysfunction syndrome and death than oxygen-derived variables in patients with sepsis. Chest. 1993; 104(I):225-9.

7. Maynard N, Bihari D, Beale R, Smithies M, Baldock G, Mason R, et al. Assessment of splanchnic oxygenation by gastric tonometry in patients with acute circulatory failure. JAMA. 1993;270( I 0): 1 203-10.

8. Gutierrez G, Bismar H, Dantzker DR, Silva N. Comparison of gastric intramucosal $\mathrm{pH}$ with measures of oxygen transport and consumption in critically ill patients. Crit Care Med. 1992;20(4):45 I-7.

9. Meregalli A, Oliveira RP, Friedman G. Occult hypoperfusion is associated with increased mortality in hemodynamically stable, high-risk, surgical patients. Crit Care. 2004;8(2):R60-R5.

10. Barquist E, Kirton O, Windsor J, Hudson-Civetta J, Lynn M, Herman M, et al. The impact of antioxidant and splanchnic-directed therapy on persistent uncorrected gastric mucosal $\mathrm{pH}$ in the critically injured trauma patient. J Trauma. 1998;44(2):355-60.

II. Kirton OC, Windsor J, Wedderburn R, Hudson-Civetta J, Shatz DV, Mataragas NR, et al. Failure of splanchnic resuscitation in the acutely injured trauma patient correlates with multiple organ system failure and length of stay in the ICU. Chest. 1998; I 13(4): 1064-9.

12. Roumen RM, Vreugde JP, Goris RJ. Gastric tonometry in multiple trauma patients. J Trauma. 1994; 36(3):313-6.

13. Claridge JA, Crabtree TD, Pelletier SJ, ButlerK, Sawyer RG, Young JS. Persistent occult hypoperfusion is associated with a significant increase in infection rate and mortality in major trauma patients. J Trauma. 2000;48(I):8- I4.

14. Fiddian-Green RG. Associations between intramucosal acidosis in the gut and organ failure. Crit Care Med. 1993:21 (2 Suppl):S I03-S7.

15. Kaplan JL, Kellum JA. Initial pH, base deficit, lactete, anion gap, strong ion diffrence, and strong ion gap predict outcome from major vascular injury. Crit Care Med. 2004;32(5): I I 20-4.

16. Ivatury RR, Simon RJ, Islam S, Fueg A, Rohman M, Stahl WM. A prospective randomized study of end points of resuscitation after major trauma: global oxygen transport indices versus organ-specific gastric mucosal pH. J Am Coll Surg. 1996; 183(2): 145-54.

17. Gutierrez G, Palizas F, Doglio G, Wainsztein N, Gallesio A, Pacin J, et al. Gastric intramucosal $\mathrm{pH}$ as a therapeutic index of tissue oxygenation in critically ill patients. Lancet. 1992;339(8787): 195-9.
18. Miami Trauma Clinical Trials Group. Splanchnic hypoperfusion-directed therapies in trauma: a prospective, randomized trial. Am Surg. 2005;7I(3):252-60.

19. Takala J, Parviainen I, Siloaho M, Ruokonen E, Hamalainen E. Saline PCO2 is an important source of error in the assessment of gastric intramucosal pH. Crit Care Med. 1994;22( I I): 1877-9.

20. Vincent JL, Creuter J. Gastric intramucosal pH is definitely obselete-please tell us more about gastric intramucosal PCO2. Crit Care Med. 1998;26(8): | 479-8|.

21. Chapman MV, Mythen MG, Webb AR, Vincent JL. Report from meeting: gastrointestinal tonometry: state of the art. Intensive Care Med. 2000;26(5):613-22.

22. Schlichtig R, Mehta N, Gayowski TJ. Tissue-arterial PCO2 difference is a better marker of ischemia than intramural $\mathrm{pH}(\mathrm{pHi})$ or arterial $\mathrm{pH}-\mathrm{pHi}$ difference. J Crit Care. 1996; I I(5):5 I0-56.

23. Gomersall CD, Joynt GM, Ho KM, Young RJ, Buckley TA, Ohm TE. Gastric tonometry and prediction of outcome in the critically ill. Arterial to intramucosal $\mathrm{pH}$ gradient and carbon dioxide gradient. Anaesthesia. 1997;52(6):619-23.

24. Miller PR, Kincaid EH, Meredith JW, Chang MC. Threshold values of intramucosal $\mathrm{pH}$ and mucosal-arterial $\mathrm{CO} 2$ gap during shock resuscitation. J Trauma. 1998;45(7):868-72.

25. Levy B, Gawalkiewicz P, Vallet B, Briancon S, Nace L, Bollaert PE. Gastric capnometry with air-automated tonometry predicts outcome in critically ill patients. Crit Care Med. 2003;3 I(5):474-80.

26. Vincent JL, De Mendonca A, Cantraine F, Moreno R, Takala J, Suter PM, et al. Use of the SOFA score to assess the incidence of organ dysfunction/ failure in intensive care units: results of a multicenter, prospective study. Crit Care Med. 1998;26(I2): 1793-1800.

27. Knaus WA, Draper EA, Wagner DP, Zimmerman JE. APACHE II: a severity of disease classification system. Crit Care Med. 1985; I 3(10):818-29.

28. Gunnerson KJ, Saul M, He S, Kellum JA. Lactate versus non-lactate metabolic acidosis: a retrospective outcome evaluation of critically ill patients. Crit Care. 2006; I O(I):R22.

29. Chang MC, Cheatham ML, Nelson LD, Rutherford EJ, Morris JAJr. Gastric tonometry supplements information provided by systemic indicators of oxygen transport. J Trauma. 1994; 37(3):488-94.

30. Blow O, Magliore L, Claridge JA, Butler K, Young JS. The golden hour and the silver day: detection and correction of occult hypoperfusion within 24 hours improves outcome from major trauma. J Trauma. 1999;47(5):964-9.

3I. Manikis P, Jankowski S, Zhang H, Kahn RJ, Vincent JL. Correlation of serial blood lactate levels to organ failure and mortality after trauma. Am J Emerg Med. 1995;13(6):619-22.

32. Rutherford EJ, Morris JA Jr, Reed GW, Hall KS. Base deficit stratifies mortality and determines therapy. J Trauma. 1992;33(3):4 I7-23.

33. Davis JW, Kaups KL, Parks SN. Base deficit is superior to $\mathrm{pH}$ in evaluating clearance of acidosis after traumatic shock. J Trauma. 1998;44( I): I | 4-8.

34. Spahn DR, Cerny V, Coats TJ, Duranteau J, Fernandez-Mondejar E, Gordini G, et al. Management of bleeding following major trauma: a European guideline. Crit Care. 2007; I I ( I):RI7.

35. Husain FA, Martin MJ, Mullenix PS, Steele SR, Elliott DC. Serum lactate and base deficit as predictors of mortality and morbidity. Am J Surg. 2003; | 85(5):485-9|.

36. Martin MJ, FitzSullivan E, Salim A, Berne TV, Towfigh S. Use of serum bicarbonate measurement in place of arterial base deficit in the surgical intensive care unit. Arch.Surg. 2005; | 40(7):745-51.

37. Boyd O, Mackay CJ, Lamb G, Bland JM, Grounds RM, Bennett ED. Comparison of clinical information gained from routine blood-gas analysis and from gastric tonometry for intramural $\mathrm{pH}$. Lancet. 1993;34| (8838): | 42-6.

38. Ceppa EP, Fuh KC, Bulkley GB. Mesenteric hemodynamic response to circulatory shock. Curr Opin Crit Care. 2003;9(2): 127-32.

39. Keel M, Trentz O. Pathophysiology of polytrauma. Injury. 2005;36(6):69I -709.

Artigo recebido: 31/03/07

Aceito para publicação: 08//2/07 